\title{
Evaluation the Efficacy of Certain Bio-Rational Insecticides on Tuta Absoluta (Lepidoptera, Gelechiidae) on Tomatoes under Laboratory and Field Conditions
}

\author{
Abd El-Hady, M. A., M. A. M. Osman and A. A. Sarhan \\ Plant Protection Department, Faculty of Agriculture, Suez Canal University 41522, Ismailia, Egypt
}

Received: 1/10/2013

\begin{abstract}
The tomato leaf miner (TLM), Tuta absoluta (Meyrick) (Lepidoptera: Gelechiidae) is an exotic pest on tomato plants either in open field or under protected cultivations at Ismailia Governorate and elsewhere. The efficacy of five different commercial bio-rational products viz., Coragen, Dipel 2X, Match, Proclaim and Spinosad in their recommended dose was evaluated against TLM under laboratory and field conditions. Data indicated that under laboratory conditions, the tested insecticides showed various toxicity to first and fourth instar larvae of TLM. Proclaim caused the highest accumulated mortality in TLM larvae, followed by Coragen and Spinosad 10 days post treatment. Dipel 2X and Match were slightly toxic to first instar, while Match didn't show any toxicity towards fourth instar larvae. Under field condition, the lowest number of mines (2.4 mines/plant) was recorded in Coragen treatment after 10 days of application, followed by Proclaim, Spintor, Dipel and Match compared to control at 2.7, 4, 4.1, 9.1 and 9 mines/plant, respectively. The highest percentage of reduction in infestation of TLM was recorded in Coragen, Spintor and Proclaim treatments at 68.33, 61.97 and 54.89\%, respectively. Dipel had moderate effectiveness in reduction of infestation at $42.78 \%$, while the lowest percentage of reduction in infestation was recorded in Match treatment at $27.51 \%$.
\end{abstract}

Keywords: Tuta absoluta - bioinsecticides - Tomato - mortality - infestation.

\section{INTRODUCTION}

Tuta absoluta (Meyrick) (Lepidoptera: Gelechiidae), in only a few years, has become a serious threat to global tomato production. It is now considered to be one of the most damaging invasive pests of tomatoes in the Mediterranean Basin countries such as Egypt, Tunisia, Libya, Morocco and Algeria (Caparros et al., 2012). Potential yield loss in tomatoes (quantity and quality) is significant and can reach up to $100 \%$ if the pest is not manage properly (Desneux et al., 2010). The control of TLM relies heavily on chemical control, but decreasing efficacy has been attributed to the development of insecticide resistance (Haddi, 2011). Therefore, modern integrated pest management (IPM) recommends effective pesticides that have low mammalian toxicity, low persistence in the environment, and high degree of selectivity and delay the development of resistance to other classical insecticides (Braham and Hajji, 2012). Fortunately, in Egypt, some bio-rational pesticides began to be used against this pest. The insecticide, "Emamectin benzoate" $\left(\right.$ Proclaim $^{\circledR}$ ) is a new macrocyclic lactone insecticide derived from the natural avermectin family produced by fermentation of a soil microorganism Streptomyces avermitilis (Schallman et al., 1987). The insecticide acts on the GABA receptor activating the chloride channel (Aliferis and Jabaji, 2011). This product has been developed for the control of Lepidopterous pests including TLM on a variety of vegetable crops worldwide (Liguori et al., 2008).

Chlorantraniliprole (Coragen $\AA$ ) is a new compound belonging to a new class of selective insecticides (anthranilic diamides) featuring a novel mode of action. By activating the insect ryanodine receptors (RyRs), it stimulates the release and depletion of intracellular calcium stores from the sarcoplasmic reticulum of muscle cells, causing impaired muscle regulation, paralysis and ultimately death of sensitive species (Cordova et al., 2006). It has very low toxicity for mammals (both acute and chronic), high intrinsic activity on target pests, strong ovilarvicidal and larvicidal properties, long lasting crop protection and no cross-resistance with any existing insecticide (Bassi et al., 2009). It has very high biological activity on several caterpillar species; including Carpocapsa pomonella and Leptinotarsa decemlineata (Bassi et al., 2009) with outstanding performance on TLM and an extremely low mammalian toxicity profile (Bassi et al., 2012).

Spinosad $\left(\right.$ Spintor $^{\circledR}$ ) is a biopesticide produced through the fermentation of the soil actinomycete, Saccharopolyspora spinosa Mertz \& Yao (Thompson and Hutchins, 1999). Its active ingredient consists of a mixture of spinosyn A and spinosyn D (Salgado, 1998). Because of its unique mode of action, involving the postsynaptic nicotinic acetylcholine and GABA receptors, spinosad has strong insecticidal activity against insects (Salgado, 1998) especially Lepidoptera (Wang et al., 2009).

Lufenuron (Match $\left.{ }^{\circledR}\right)$ is an acylurea insect growth regulator belonging to the group of benzoyl-phenylureas (BPUs) and is classified as an insect development inhibitor (IDI). Like all BPU's, lufenuron interferes with chitin biosynthesis acts mainly by ingestion (Arora et al., 2011). Insect growth regulators like lufenuron are claimed to be safe and have little impact on beneficial arthropods as compared to conventional insecticides (Whiting et al., 2000).

Dipel $2 \mathrm{X}^{\circledR}$ is Bacillus thuringiensis v. kurstaki based insecticides (Lambert and Peferoen, 1992). The insecticidal activity of $B$. thuringiensis is attributed to the parasporal crystals, known as delta endotoxins or insecticidal crystal proteins (ICP) (Xavier et al., 2007), which are toxic to the larval stage of the insects belonging to Lepidoptera, Diptera, and Coleoptera 
(Schneph et al., 1998). Bt-based insecticides are harmless to most wildlife and beneficial insects (De Maagd et al., 2001).

Therefore, the current research aimed to determine the efficacy of Proclaim, Coragen, Spinosad, Dipel 2X and Match against TLM under laboratory and field conditions.

\section{MATERIALS AND METHODS}

\section{Maintenance of TLM:}

Tomato leaves bearing eggs and different larval instars of tomato leaf miner moth (TLM), Tuta absoluta were periodically collected from the TLM infested tomato fields in the Experimental Farm, Faculty of Agriculture, Suez Canal University. Larvae were reared on tomato seedlings ( $30 \mathrm{~cm}$ long) grown in plastic pots (15 cm diameter). Tomato seedlings were placed in a rearing cage $(40 \mathrm{~cm}$ in width $\times 60 \mathrm{~cm}$ in length $\times 80 \mathrm{~cm}$ in height), three of its sides covered by organza and one covered with glass. These cages were kept under the laboratory conditions of $25 \pm 2{ }^{\circ} \mathrm{C} ; 60 \pm 10 \% \mathrm{RH}$ and photoperiod of 14/10 (L/D) h. After the completion of the immature development, TLM pupae were collected, kept in clean Petri dishes and placed in clean glass jars $(30 \times 15 \mathrm{~cm})$ until moth emergence and fed on sucrose solution (10\%). Upon emergence, adults of TLM were collected, transferred to other rearing cage as previously mentioned for rearing of TLM larvae, and provided with tomato seedlings as an ovipositional substrate to maintain the culture. This cycle was repeated for at least 3 generations before being used in the intended experiments.

\section{Tested Bio-rational Insecticides}

The list of commercial formulations of the certain insecticides tested against the first and fourth instars larvae of TLM in this study are presented in (Table 1). These bio-rational insecticides were Coragen (20\% SC Chlorantraniliprole), Dipel $2 \times \quad \%, \varepsilon \quad$ (Bacillus thuringensis var. kurstaki $32000 \mathrm{IU} / \mathrm{mg})$, Match $(50 \%$ EC Lufenuron), Proclaim (5\% EC Emamectin benzoate), and Spintor 24\% SC (spinosyns A and D, Saccharopolyspora spinosa). Solutions of all tested compounds were prepared in distilled water at the recommended field rate (FR), (Coragen $60 \mathrm{mg} / \mathrm{l}$ a.i., Dipel 2x 128 mg/l a.i., Match 200 mg/l a.i., Proclaim 30 $\mathrm{mg} / \mathrm{l}$ a.i. and Spintor $60 \mathrm{mg} / \mathrm{l}$ a.i.). The tested concentrations of all tested compounds in the present study were freshly prepared one hour prior to experiments.

\section{Laboratory bioassay}

The effect of the field rates of the tested bio-rational insecticides were studied against $T$. absoluta first and fourth instar larvae. The treatments were performed using tomato seedlings (cv. GS-12) transplanted in small plastic pots $(15 \mathrm{~cm}$ diameter $)$ filled with peat moss and watered when needed. The tomato plants were maintained free of TLM infestation in the laboratory until use. One day before the assay, plants (having 4 - 6 true leaves) were artificially infested with 10 larvae / plant. The tested insecticides were sprayed using a small handle sprayer until run off. Treated plants were left for one hour to dry out, then they were kept in a glasshouse under conditions of $25 \pm 2^{\circ} \mathrm{C}$ and $60 \pm 10 \%$ R.H. Four replicates (plants) and an untreated plant was used as a control for each treatment. Data were recorded 1, 3, 5, 7 and 10 days after insecticide application in terms of dead and live larvae. The mortality rates in each treatment were calculated and corrected using Abbott's formula (Abbott, 1925) as follow:

\section{Corrected mortality $(\%)=[(\mathrm{Ck}-\mathrm{Ta}) / \mathrm{Ck}] \times 100$}

where $\mathrm{Ck}=$ number of insects in control after application, $\mathrm{Ta}=$ number of insects in the treatment after application.

\section{Field bioassay:}

The field experiments were conducted to evaluate the field efficiency of tested bio-rational insecticides against the infestation of TLM using tomato plants variety GS grown at the Experimental Farm of Agriculture Faculty, Suez Canal University. The required agricultural practices were applied except for the use of insecticide. The experiment was carried out as a randomized complete block design consisting of 6 treatments. Each treatment contained 3 plots of tomato plants $(5 \times 5 \mathrm{~m})$. Each plot consisted of 5 rows with a total of 25 plants for each experimental plot. In each treatment, ten plants represented ten replicates were selected randomly and labeled for periodical inspection and data recording. The bio-rational insecticide treatments included Match at $0.4 \mathrm{~cm} / 1$, Spintor at 0.25 $\mathrm{cm} / 1$., Dipel $2 \mathrm{x} \%$,, at $2.0 \mathrm{~g} / 1$, Proclaim at $0.6 \mathrm{~g} / 1$ and Coragen $0.3 \mathrm{~cm} / 1$. These insecticides were applied using a backpack sprayer in a broadcast application on tomato plants. Applications were preferred when tomato seedlings were at the age of about 1.5 months after transplanting, on 24 April 2013 at $9.00 \mathrm{am}$. The numbers of newly mines of TLM/10 complete leaflets/plant was recorded before and after application. Data were recorded $1,3,5,7$ and 10 days after application on ten selected plants of each treatment. To determine the effectiveness of the tested bio-rational insecticides, the percent of reductions in infestation with TLM throughout the inspection periods were estimated using Henderson and Tilton (1955) equation as follow:

Efficiency (\%) $=[1-(\mathrm{n}$ in $\mathrm{Ck}$ before treatment $* \mathrm{n}$ in $\mathrm{T}$ after treatment) / ( $\mathrm{n}$ in $\mathrm{Ck}$ after treatment $* \mathrm{n}$ in $\mathrm{T}$ before treatment) $] \times 100$

where: $\mathrm{n}=$ number of mines/plant, $\mathrm{T}=$ treated, and $\mathrm{Ck}=$ control

\section{Statistical analysis:}

Normality of data was tested by the Shapiro-Wilks test before further analysis. When a Shapiro-Wilk test indicated that data were normally distributed, data were analyzed by parametric analysis of variance (ANOVA) and then the Holm-Sidak or Student-Newman-Keuls Methods were used for all pairwise multiple comparisons. When data were not normally distributed, a nonparametric Kruskal-Wallis ANOVA on ranks (H test) was used and Tukey's or Dunn's tests were used to compare treatment means at a 0.05 level of 
significance. Data were analyzed using SigmaPlot 12.3 (Systat Software, Inc. 2011).

\section{RESULTS}

\section{Laboratory bioassay:}

The obtained data demonstrated various toxicity of the tested bio-rational insecticides at their field rates to larvae of TLM (Tables 1 and 2). It is also, confirmed the insecticidal potency of emamectin benzoate represented as Proclaim, on both TLM larval instars at 1, 3, 5, 7 and 10 days post treatment compared to the rest of tested bio-rational insecticides. Clearly, Proclaim caused the highest accumulated mortality in TLM larvae, followed by Coragen, Spinosad, Match and Dipel 2x at 10 days post treatment.

Concerning the first instar larvae of TLM, there were significant differences between the tested biorational insecticides at their tested recommended dose in the mortality rates in first instar cohorts 1 day $\left(\mathrm{H}_{5}=\right.$ $16.53 ; P=0.005), 3$ days $\left(\mathrm{F}_{5,54}=12.28 ; P=0.001\right), 5$ days $\left(\mathrm{F}_{5,54}=16.10 ; P=0.001\right), 7$ days $\left(\mathrm{F}_{5,54}=16.62 ; P=\right.$ $0.001)$, and 10 days $\left(\mathrm{F}_{5,54}=16.62 ; P=0.001\right)$ post treatment. No significant differences were observed between Match and Dipel $2 \times$ treatments with control treatment (Table 1).

Pertaining to the fourth instar larvae of TLM, data indicated that mortality in fourth instar larvae is in the order of Proclaim $>$ Coragen $>$ Spintor $>$ Dipel $2 \times>$ Match. Significant differences existed among the tested bio-rational insecticides in the mortality rates in $4^{\text {th }}$ larval instar cohorts 1 day $\left(\mathrm{H}_{5}=14.05 ; P=0.015\right), 3$ days $\left(\mathrm{F}_{5,54}=23.89 ; P=0.001\right), 5$ days $\left(\mathrm{F}_{5,54}=17.53 ; P=\right.$ $0.001), 7$ days $\left(\mathrm{F}_{5,54}=21.71 ; P=0.001\right)$, and 10 days $\left(\mathrm{F}_{5,54}=21.71 ; P=0.001\right)$ post treatment (Table 2$)$.

\section{Field Experiment:}

The number of newly formed mines by larvae of TLM within tomato leaves before spraying and up to 10 days after field application are presented in (Table 3). Generally, the number of mines/plant differed among different treatments and control irrespective of interval of inspection. The lowest number of mines $(2.4$ mines/plant) was recorded in Coragen treatment after 10 days of treatment, followed by Proclaim, Spintor, Dipel 2x and Match compared to control at 2.7, 4, 4.1, 9.1 and 9 mines/plant, respectively.

Statistical analyses revealed that the tested biorational insecticides yielded significant decrease in the number of TLM mines/plant under field conditions 1 day $\left(\mathrm{F}_{5,54}=6.83 ; P=0.036\right), 3$ days $\left(\mathrm{F}_{5,54}=7.97 ; P=\right.$ $0.001), 5$ days $\left(\mathrm{F}_{5,54}=8.40 ; P=0.001\right), 7$ days $\left(\mathrm{F}_{5,54}=\right.$ $13.12 ; P=0.001)$ and 10 days $\left(\mathrm{F}_{5,54}=12.84 ; P=0.001\right)$ post treatment (Table 3 ).

Data presented in Table (4) indicated that all biorational insecticides under field conditions caused noticeably reduction in TLM infestations. The highest percent of reduction was recorded in Coragen, Spintor and Proclaim at 68.33, 61.97 and 54.89\%, respectively. Dipel $2 \times$ had moderate effectiveness in reduction of infestation at $42.78 \%$. Obviously, the lowest percentage of reduction in TLM infestation was recorded in Match treatment as $27.51 \%$.

Table (1): Mortality $(\% \pm \mathrm{SE})$ in TLM first instar larvae fed on tomato seedlings treated with the recommended field rates of certain bio-rational insecticides at different intervals post application

\begin{tabular}{|c|c|c|c|c|c|c|}
\hline \multirow{2}{*}{ Treatment } & \multirow{2}{*}{$\begin{array}{c}\text { Concentration } \\
\text { mg/l a.i. }\end{array}$} & \multicolumn{5}{|c|}{$\%$ Mortality in first instar larvae after, } \\
\hline & & 1 day & 3 days & 5 days & 7 days & 10 days \\
\hline Control & --- & $2.50 \pm 2.50^{\mathrm{bc}}$ & $15.00 \pm 5.00^{b}$ & $22.50 \pm 6.29^{b}$ & $25.00 \pm 6.45^{b}$ & $15.00 \pm 6.45^{b}$ \\
\hline Coragen & $60 \mathrm{mg} / \mathrm{l}$ & $25.00 \pm 10.41^{\mathrm{ab}}$ & $57.50 \pm 2.50^{\mathrm{a}}$ & $80.00 \pm 7.07^{\mathrm{a}}$ & $87.50 \pm 7.50^{\mathrm{a}}$ & $87.50 \pm 7.50^{\mathrm{a}}$ \\
\hline Dipel 2x & $128 \mathrm{mg} / 1$ & $0^{\mathrm{c}}$ & $7.50 \pm 4.78^{b}$ & $15.00 \pm 6.45^{b}$ & $15.00 \pm 6.45^{b}$ & $15.00 \pm 6.45^{b}$ \\
\hline Match & $200 \mathrm{mg} / \mathrm{l}$ & $2.50 \pm 2.50^{\mathrm{bc}}$ & $12.50 \pm 4.78^{b}$ & $20.00 \pm 5.77^{\mathrm{b}}$ & $25.00 \pm 6.45^{\mathrm{b}}$ & $25.00 \pm 6.45^{b}$ \\
\hline Proclaim & $30 \mathrm{mg} / \mathrm{l}$ & $27.50 \pm 4.78^{\mathrm{a}}$ & $55.00 \pm 6.45^{\mathrm{a}}$ & $90.00 \pm 4.08^{\mathrm{a}}$ & $97.50 \pm 2.50^{\mathrm{a}}$ & $97.50 \pm 2.50^{\mathrm{a}}$ \\
\hline Spintor & $60 \mathrm{mg} / \mathrm{l}$ & $35.00 \pm 6.45^{\mathrm{a}}$ & $52.50 \pm 6.29^{\mathrm{a}}$ & $65.00 \pm 6.45^{\mathrm{a}}$ & $65.00 \pm 6.45^{\mathrm{a}}$ & $65.00 \pm 6.45^{\mathrm{a}}$ \\
\hline$P$ & & 0.005 & 0.001 & 0.001 & 0.001 & 0.001 \\
\hline
\end{tabular}

Means within a column followed by different letters are significantly different: $\mathrm{P}<0.05$; Tukey Test (1 day post application); or Holm-Sidak Method (3, 5,7 and 10 days post application).

Table (2): Mortality $(\% \pm$ SE) in TLM fourth instar larvae fed on tomato seedlings treated with the recommended field rates of certain bio-rational insecticides at different intervals post application

\begin{tabular}{|c|c|c|c|c|c|c|}
\hline \multirow{2}{*}{ Treatment } & \multirow{2}{*}{$\begin{array}{c}\text { Concentration } \\
\text { mg/l a.i. }\end{array}$} & \multicolumn{5}{|c|}{ \% Mortality in fourth instar larvae after, } \\
\hline & & 1 day & 3 days & 5 days & 7 days & 10 days \\
\hline Control & --- & $0^{\mathrm{a}}$ & $2.50 \pm 2.50^{b}$ & $7.50 \pm 4.79^{c}$ & $7.50 \pm 4.79^{d}$ & $7.50 \pm 4.79^{\mathrm{d}}$ \\
\hline Coragen & $60 \mathrm{mg} / 1$ & $17.50 \pm 8.54^{\mathrm{a}}$ & $55.00 \pm 5.00^{\mathrm{a}}$ & $67.50 \pm 7.50^{\mathrm{ab}}$ & $75.00 \pm 6.46^{\mathrm{ac}}$ & $75.00 \pm 6.46^{\mathrm{ac}}$ \\
\hline Dipel 2x & $128 \mathrm{mg} / 1$ & $17.50 \pm 4.78^{\mathrm{a}}$ & $30.00 \pm 9.13^{\mathrm{a}}$ & $32.50 \pm 8.54^{b}$ & $37.50 \pm 7.50^{\mathrm{bc}}$ & $37.50 \pm 7.50^{b c}$ \\
\hline Match & $200 \mathrm{mg} / 1$ & $0^{\mathrm{a}}$ & $0^{\mathrm{b}}$ & $2.50 \pm 2.50^{\mathrm{c}}$ & $2.50 \pm 2.50^{\mathrm{d}}$ & $2.50 \pm 2.50^{\mathrm{d}}$ \\
\hline Proclaim & $30 \mathrm{mg} / \mathrm{l}$ & $7.50 \pm 2.50^{\mathrm{a}}$ & $45.00 \pm 6.46^{\mathrm{a}}$ & $77.50 \pm 4.79^{\mathrm{a}}$ & $82.50 \pm 2.50^{\mathrm{a}}$ & $82.50 \pm 2.50^{\mathrm{a}}$ \\
\hline Spintor & $60 \mathrm{mg} / \mathrm{l}$ & $7.50 \pm 2.50^{\mathrm{a}}$ & $30.00 \pm 8.17^{\mathrm{a}}$ & $30.00 \pm 8.17^{b}$ & $32.50 \pm 8.54^{b}$ & $32.50 \pm 8.54^{b}$ \\
\hline$P$ & & 0.015 & 0.001 & 0.001 & 0.001 & 0.001 \\
\hline
\end{tabular}

Means within a column followed by different letters are significantly different: $\mathrm{P}<0.05$; Tukey Test (1 day post application); or Holm-Sidak Method (3, 5, 7 and 10 days post application). 
Table (3): Mean ( \pm SE) of newly formed mines/tomato plant of TLM before and after different intervals post treatment with recommended field rate of certain bio-rational insecticides

\begin{tabular}{|c|c|c|c|c|c|c|c|}
\hline \multirow{3}{*}{ Treatment } & \multirow{3}{*}{ Field rates } & \multicolumn{6}{|c|}{ Mean ( \pm SE) of newly formed mines/plant } \\
\hline & & \multirow{2}{*}{$\begin{array}{c}\text { Before } \\
\text { treatment }\end{array}$} & \multicolumn{5}{|c|}{$\begin{array}{l}\text { After treatment } \\
\end{array}$} \\
\hline & & & 1 day & 3 days & 5 days & 7 days & 10 days \\
\hline Control & --- & $8.90 \pm 1.74^{\mathrm{ab}}$ & $10.30 \pm 1.34^{\mathrm{ac}}$ & $8.70 \pm 1.18^{\mathrm{a}}$ & $4.10 \pm 0.62^{\mathrm{a}}$ & $8.50 \pm 0.96^{\mathrm{a}}$ & $9.00 \pm 1.17^{\mathrm{a}}$ \\
\hline Coragen & $0.30 \mathrm{~cm} / 1$ & $10.50 \pm 1.17^{\mathrm{ab}}$ & $6.20 \pm 0.80^{\mathrm{bc}}$ & $4.00 \pm 0.63^{b c}$ & $1.20 \pm 0.44^{\mathrm{b}}$ & $2.10 \pm 0.50^{b}$ & $2.40 \pm 0.81^{\mathrm{b}}$ \\
\hline Dipel 2x & $2.00 \mathrm{~g} / 1$ & $10.30 \pm 1.47^{\mathrm{ab}}$ & $7.80 \pm 0.74^{b c}$ & $7.50 \pm 0.89^{\mathrm{ab}}$ & $2.80 \pm 0.55^{\mathrm{ab}}$ & $4.70 \pm 0.91^{\mathrm{bc}}$ & $4.10 \pm 0.64^{b}$ \\
\hline Match & $0.40 \mathrm{~cm} / 1$ & $12.60 \pm 1.67^{\mathrm{a}}$ & $12.70 \pm 1.55^{\mathrm{a}}$ & $8.60 \pm 1.43^{\mathrm{a}}$ & $4.60 \pm 0.69^{\mathrm{a}}$ & $6.60 \pm 0.82^{\mathrm{ac}}$ & $9.10 \pm 0.90^{\mathrm{a}}$ \\
\hline Proclaim & $0.60 \mathrm{~g} / 1$ & $6.30 \pm 0.75^{b}$ & $4.70 \pm 0.70^{b}$ & $2.60 \pm 0.64^{\mathrm{c}}$ & $1.40 \pm 0.49^{b}$ & $1.70 \pm 0.39^{b}$ & $2.70 \pm 0.73^{b}$ \\
\hline Spintor & $0.25 \mathrm{~cm} / 1$ & $10.80 \pm 1.94^{\mathrm{ab}}$ & $8.90 \pm 1.17^{\mathrm{ab}}$ & $3.70 \pm 0.72^{b c}$ & $1.00 \pm 0.37^{\mathrm{b}}$ & $2.80 \pm 0.74^{b}$ & $4.00 \pm 0.75^{b}$ \\
\hline$P$ & & 0.036 & 0.001 & 0.001 & 0.001 & 0.001 & 0.001 \\
\hline
\end{tabular}

Means within a column followed by different letters are significantly different: $\mathrm{P}<0.05$; Tukey Test (before treatment); or Holm-Sidak Method (1,3, 5 , 7 and 10 days after treatment).

Table (4): Percentages of reduction* in TLM infestation in tomato plants after different intervals post treatment with certain bio-rational insecticides under field conditions.

\begin{tabular}{lccccccc}
\hline \multirow{2}{*}{ Treatment } & \multirow{2}{*}{ Field rates } & \multicolumn{7}{c}{ \% Reduction of infestation after * } & \multirow{2}{*}{ \% Effectiveness } \\
\cline { 3 - 8 } & & $\mathbf{1 ~ d a y}$ & $\mathbf{3 ~ d a y s}$ & $\mathbf{5}$ days & $\mathbf{7 ~ d a y s}$ & $\mathbf{1 0}$ days & 68.33 \\
Coragen & $0.3 \mathrm{~cm} / 1$ & 48.98 & 61.03 & 75.19 & 79.06 & 77.39 & 42.78 \\
Dipel 2x & $2.0 \mathrm{~g} / 1$ & 34.56 & 25.51 & 40.99 & 52.22 & 60.64 & 27.51 \\
Match & $0.4 \mathrm{~cm} / 1$ & 12.91 & 30.18 & 20.75 & 45.15 & 28.58 & 54.89 \\
Proclaim & $0.6 \mathrm{~g} / 1$ & 35.54 & 57.78 & 51.76 & 71.74 & 57.62 & 61.97 \\
Spintor & $0.25 \mathrm{~cm} / 1$. & 28.79 & 64.95 & 79.90 & 72.85 & 63.37 & \\
\hline
\end{tabular}

* Percent reduction in infestation was estimated according to Henderson and Tilton (1955)

\section{DISCUSSION}

The current management of TLM in the Mediterranean Basin is mainly based on treatments with chemical insecticides (Gonzalez-Cabrera et al., 2011). Nevertheless, few active ingredients are effective against TLM and selective to beneficial insects at the same time. The obtained results from laboratory and field trials showed that the Emamectin benzoate-basedinsecticides Proclaim $^{\circledR}$, had the greatest efficacy with mortality rates of 97.50 and $82.50 \%$ against first and fourth instar larvae, respectively. These findings are in conformity with those reported earlier by Gacemi and Guenaoui (2012), who found that the biopesticide Emamectin benzoate caused an acceptable mortality against larvae of TLM at 87\%. Also, López et al. (2010a) observed a mortality rate of $90 \%$ in larvae of TLM on tomato leaves. Likewise, Emamectin benzoate was found to be effective against other pests such as Helicoverpa zea Boddie (López et al., 2010b) and Spodoptera littoralis Boisd (Abou-Taleb et al., 2008).

A high toxicity of Chlorantraniliprole $\left(\right.$ Coragen $\left.^{(}\right)$ was observed against both tested larval instars of TLM, with outstanding performance under field conditions. Early results were promising, even on insecticideresistant populations with extremely low mammalian toxicity profile (Dinter et al., 2008). Coragen has also demonstrated outstanding $C$. pomonella control either alone or in an alternation program with Steward $\AA$ (Indoxacarb) (Bassi et al., 2009).

Spinosad (Spintor) showed high toxicity on first compared to fourth instar larvae of TLM in laboratory; also high efficiency was confirmed in terms of reduction in TLM infestation under field conditions. These findings are in agreement with those reported earlier by Nannini et al. (2011) who mentioned that Spinosad proved to be highly effective against TLM larvae with considerably decreased pest infestation under semi-field conditions as compared toIndoxacarb, metaflumizone, azadirachtin, and abamectin. Furthermore, Spinosad also showed high efficacy against other lepidoptrous pests, such as Palpita unionalis (Hübner) (Mandour et al., 2008), Agrotis ipsilon Mahmoud (2004) and S. littoralis (Aydin and Gurkan, 2005).

With respect to $B$. thuringiensis (Dipel $2 \times^{\circledR}$ ), the obtained data showed low toxicity to both tested TLM larval instars under laboratory conditions. This conclusion was in agreement with that reported by Nannini et al. (2011). They stated that products of $B$. thuringiensis subsp. Aizawai were less active in glasshouse applications compared to laboratory conditions. However, this conclusion was inconsistent with those obtained by Gonzalez-Cabrera et al. (2011) who mentioned that $B$. thuringiensis-basted insecticide was highly efficient in controlling TLM in laboratory, greenhouse, and open-field experiments and first instar larvae were the most susceptible, while lower susceptibility was observed in second and third instar larvae. Also, Giustolin et al. (2001) found that Btk can cause high mortality in all TLM instars and that the use of Btk has synergistic or additive effects when applied to tomato resistant genotypes.

Lufenuron $\left(\right.$ Match $\left.^{\circledR}\right)$ showed very low toxicity against the first instar larvae of TLM, but no toxicity was observed against fourth instar larvae with subsequent lower reduction in TLM infestation under field conditions. These results are in disagreement with those reported by Osman and Mahmoud (2008) who 
demonstrated that Match $^{\circledR}$ gave $100 \%$ mortality of $5^{\text {th }}$ instar larvae of $S$. littoralis.

In conclusion, the five tested bio-rational insecticides had various toxic effects on first and fourth instar larvae of TLM under laboratory condition. Also, these insecticides showed dissimilar levels of reduction in infestation of TLM under field condition. Emamectin benzoate was the most toxic to larvae of TLM. Chlorantraniliprole demonstrated strong activity, Spinosad had high toxic effect especially against earlier instar larvae, greatly decreased the infestation rate. Bacillus thuringiensis seemed to have moderate effect since it has been able to reduce somewhat the pest infestation. Lufenuron didn't able to manage the insect infestation. The results showed that all tested insecticide, except Match, were effective to control TLM and might be used to control this pest outbreaks. The results gave an acceptable efficacy of the biopesticide Emamectin-benzoate, Chlorantraniliprole and Spinosad against the tomato leafminer TLM Meyrick (Lepidoptera: Gelechiidae). Hence, such these bioinsecticide will continue to be an integral component of pest management programs due mainly to their effectiveness and selectivity.

\section{REFERENCES}

Abbott, W.S. (1925). A method for computing the effectiveness of an insecticide. Journal of Economic Entomology, 18:265-267.

Abou-Taleb, K.; Abdel Rahman, S.M. and Sherby, S.M. (2008). Efficacy of some natural oils on the residual toxicity of emamectin benzoate, spinosad and spinetoram against cotton leafworm. Journal of Pest Control and Environmental Sciences, 16(1/2):37-56.

Aliferis, K.A. and Jabaji, S. (2011). Metabolomics- A robust bioanalytical approach for the discovery of the modes of action of pesticides: A review. Pesticide Biochemistry and Physiology, 100:105117.

Arora, M.S.; Salokhe, S.G. and Mukherjee, S.N. (2011). Effect of sub-lethal concentrations of lufenuron on growth, development and reproductive performance of Tribolium castaneum (Herbst) (Coleoptera: Tenebrionidae). International Journal of Applied Biology and Pharmaceutical Technology, 3(1):111-122.

Aydin, H. and Gurkan, M.O. (2005). The efficacy of spinosad on different strains of Spodoptera littoralis (Boisduval) (Lepidoptera: Noctuidae). Turkish Journal of Biology, 30:5-9.

Braham, M. and Hajji, L. (2012). Management of Tuta absoluta (Lepidoptera, Gelechiidae) with insecticides on tomatoes, Insecticides - Pest Engineering, Dr. Farzana Perveen (Ed.), ISBN: 978-953-307895-3, InTech, Available from: http://www.intechopen.com/books/insecticidespest-engineering/managementof-tuta-absolutalepidoptera-gelechiidae-with-insecticides-ontomatoes.

Bassi, A.; Rison, J.L. and Wiles, J.A. (2009). Chlorantraniliprole (DPX-E2Y45, Rynaxypyr ${ }^{(\mathrm{R})}$,
Coragen $\left.{ }^{(\mathrm{R})}\right)$, a new diamide inseticide for control of codling moth (Cydia pomonella), colorado potato beetle (Leptinotarsa decemlineata) and European grapevine moth (Lobesia botrana). Plant Protection Society of Slovenia, $9^{\text {th }}$ Slovenian conference on plant protection. Nova Gorica, 39-46.

Bassi, A.; Rison, J.L.; Roditakis, E. and Sannino, L. (2012). Chlorantraniliprole (Rynaxypyr, Altacor) key features for sustainable control of Tuta absoluta. Integrated Control in Protected Crops, Mediterranean Climate, IOBC-WPRS Bulletin, 80:193-198.

Caparros, M.R.; Haubruge, E. and Verheggen, F. (2012). First evidence of deuterotokous parthenogenesis in the tomato leafminer, Tuta absoluta (Meyrick) (Lepidoptera: Gelechiidae). Journal of pest Science, 85(4): 409-412.

Cordova, D.; Benner, E.A.; Sacher, M.D.; Rauh, J.J.; Sopa, J.S.; Lahm, G.P.; Selby, TP.; Stevenson, T.M.; Flexner, L.; Gutteridge, S.; Rhoades, D.F.; Wu, L.; Smith, R.M. and Tao, Y. (2006). Anthranilic diamides: A new class of insecticides with a novel mode of action, ryanodine receptor activation. Pesticide Biochemistry and Physiology, 84:196-214A.

De Maagd, RA.; Alejandra, B. and Crickmore, N. (2001). How Bacillus thuringiensis has evolved specific toxins to colonize the insect world. Trends in Genetics, 17(4): 193-199.

Desneux, N.; Wajnberg, E.; Wyckhuys, K.A.G.; Burgio, G.; Arpaia, S.; Narváez-Vasquez, C. A.; lezCabrera, J.G.; Ruescas, D.C.; Tabone, E.; Frandon, J.; Pizzol, J.; Poncet, Ch.; Cabello, T. and Urbaneja, A. (2010). Biological invasion of European tomato crops by Tuta absoluta: ecology, geographic expansion and prospects for biological control. Journal of Pest Science, 83:197-215.

Dinter, A.; Brugger, K.; Bassi, A.; Frost, N.M. and Woodward, M.D. (2008). Chlorantraniliprole (DPX-E2Y45, Rynaxypyr ${ }^{\circledR}$ ) (Coragen ${ }^{\circledR}$ 20SC and Altacor ${ }^{\circledR}$ 35WG) - a novel DuPont anthranilic diamide insecticide - demonstrating low toxicity and low risk for beneficial insects and predatory mites. IOBC /WPRS Bulletin, 35:128-135.

Gacemi, A. and Guenaoui, Y. (2012). Efficacy of emamectin benzoate on Tuta absoluta Meyrick (Lepidoptera: Gelechiidae) infesting a protected tomato crop in Algeria. Academic Journal of Entomology, 5(1):37-40.

Giustolin, T.A.; Vendramim, J.D.; Alves, S.B.; Vieira, S.A. and Pereira, R.M. (2001). Susceptibility of Tuta absoluta (Meyrick) (Lepidoptera: Gelechiidae) reared on two species of Lycopersicon to Bacillus thuringiensis var. kurstaki. Journal of Applied Entomology, 125(9/10):551-556.

Gonzalez-Cabrera, J.; Molla, O.; Monton, H. and Urbaneja, A. (2011). Efficacy of Bacillus thuringiensis (Berliner) in controlling the tomato 
borer, Tuta absoluta (Meyrick) (Lepidoptera: Gelechiidae). BioControl, 56(1):71-80.

Haddi, K. (2011). Studies on insecticide resistance in Tuta absoluta (Meyrick), with special emphasis on characterisation of two target site mechanisms. PhD. Thesis. Department of Agrifood and environmental system management, Faculty of Agriculture, University of Catania, $148 \mathrm{pp}$.

Henderson, C.F. and Tilton, E.W. (1955). Tests with acaricides against brown wheat mite. Journal of Economic Entomology, 48:157-161.

Lambert, B and Peferoen, M (1992). Insecticidal promise of Bacillus thuringiensis. Facts and mysteries about a successful biopesticide. BioScience, 42: 112-122.

Liguori, R.; Cestari, P.; Serrati L. and Fusarini, L. (2008). Emamectina benzoato (Affirm $\left.{ }^{\circledR}\right)$ : innovative insetticida par la difesa contro i lepidopteri fitofagi. Atti Giornate Fitopatologiche, pp: 23-28.

López, J.M.; Artín, L.M.; López, A.; Correia, R.; González, F.; Sanz, E.; Gallardo, M. and Cantus, J.M. (2010a). Affirm ${ }^{\circledR}$ (Emamectin), a new weapon against Tuta absoluta and other lepidopteran. Phytoma-Spain, 217:5.

López, J.D.; Latheef, M.A. and Hoffman, W.C. (2010b). Effect of emamectin benzoate on mortality, proboscis extension, gustation and reproduction of the corn earworm Helicoverpa zea. Journal of Insect Science, 10:89.

Mahmoud, B.A. (2004). Spinosad as a new biopesticide against the greasy cutworm Agrotis ipsilon (Hnuf.). Agricultural Research Journal, Suez Canal University, 4:137-141.

Mandour, N.S.; Osman, M.A.M.; Mahmoud, M.F. and Mosleh, Y.Y. (2008). Evaluation of Spinosad as a Biopesticide for Controlling the Jasmine Moth, Palpita unionalis Hb. (Lepidoptera: Pyralidae). Egyptian Journal of Biological Pest Control, 18(1):207-213.

Nannini, M.; Foddi, F.; Murgia, G.; Pisci, R. and Sanna, F. (2011). Insecticide efficacy trails for management of the Tomato borer Tuta absoluta
(Meyrick) (Lepidoptera: Gelechiidae), A pest in Sardinia (Italy). Acta Horticulture (ISHS), 917:47-53.

Osman, M.A.M. and Mahmoud, M.F. (2008). Effect of bio-rational insecticides on some biological aspects of the Egyptian cotton leafworm Spodoptera littoralis (Boisd.) (Lepidoptera: Noctuidae). Plant Protection Science, 44(4):147154.

Salgado, VL. (1998). Studies on the modes of action of spinosad: Insect symptoms and physiological correlates. Pestic. Biochem. Phys., 60: 91-102.

Schallman, M.D.; Valentino, D.; Streicher, S. and Ruby, C. (1987). 'Streptomyces avermitilis' mutants defective in methylation of avermectins. Antimicrobial Agents and Chemtherapy, Mai, pp: 744-747.

Schneph, E.; Crickmore. N.; Van Rie, J.; Lereclus, D.; Baum, J.; Fietelson, J.; Zeigler, DR. and Dean, DH. (1998). Bacillus thuringiensis and its pesticidal crystal proteins. Microbiology and Molecular Biology Reviews, 62: 775-806.

Systat Software, Inc. (2011). SigmaPlot for Windows, version 12.3. Systat Software, Inc., Chicago, IL, USA.

Thompson, G. and Hutchins, S. (1999). Spinosad. Pestic. Outlook, 10: 78-81.

Wang, D.; Cong, P.Y.; Li, M.; Qui, X.H. and Wang, K.Y. (2009). Sublethal effects of Spinosad on survival, growth and reproduction of Helicoverpa armigera (Lepidoptera: Noctuidae). Pest. Man. Sci., 65: 223-227.

Whiting, D.C.; Jamieson, L.E. and Connolly, P.G. (2000). Pre - and post-harvest effects of lufenuron on Epiphyas postvittana (Lepidoptera: Tortricidae). Journal of Economic Entomology, 93(3): 673-679.

Xavier, R.; Nagarathinam, P.; Gopalakrishnan; Murugan, V. and Jayaraman, K. (2007). Isolation of lepidopteran active native Bacillus thuringiensis strains through PCR panning. Asia Pacific Journal of Molecular Biology and Biotechnology, 15(2): 61-67. 